\title{
JEKK
}

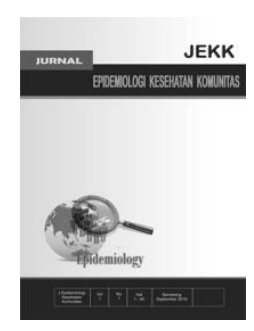

\section{Comparison of Antibacterial Activity of Sambiloto (Andrographis paniculata) Ethanol and Water Stem Extract Against Methicillin-Resistant Staphylococcus aureus (MRSA) ATCC 3351 In Vitro}

\author{
Ni Wayan Sinta Devi Arini*, Bagus Komang Satriyasa ${ }^{* *}$, I Made Jawi $^{* *}$, Ni Wayan Sucindra Dewi* ${ }^{* *}$ Agung Wiwiek \\ Indrayani $^{* *}$ \\ "Student of Medicine and Medical Doctor Profession Education, Faculty of Medicine, Udayana University, \\ Denpasar, Bali, ** Department of Pharmacology and Therapy, Faculty of Medicine, Udayana University, \\ Denpasar, Bali
}

\begin{abstract}
Background: Methicillin-resistant Staphylococcus aureus (MRSA) is penicillin and cephalosporine resistant Staphylococcus aureus which is a major cause of nosocomial infection. Various studies have been conducted for resistant cases, especially herbs which have antibacterial activity. Sambiloto (Andrographis paniculata) is an example of herb which has antibacterial activity due to the presence of andrographolide. Andrographolide soluble in ethanol and poorly in water, while extraction with alcohol causes andrographolide's degradation. This study aimed to investigate the antimicrobial activity of ethanol and water stem extract and compare them against MRSA ATCC 3351 in vitro.

Methods: This is an experimental study with a post-test only control group design and conducted by disc diffusion technique to obtain an inhibition zone against MRSA.

Result: The result of this study showed the mean inhibitory zone of ethanol stem extract was 5,87mm, $6,77 \mathrm{~mm}, 7,87 \mathrm{~mm}$ respectively for $25 \%, 50 \%$, and $100 \%$ concentrations, while $1 \%$ concentration did not show antibacterial activity. Water stem extract at 1\%,25\%,50\%, and 100\% concentrations showed mean inhibitory zone was at $4,57 \mathrm{~mm}, 7,17 \mathrm{~mm}, 8,67 \mathrm{~mm}$, and $9,67 \mathrm{~mm}$ respectively.

Conclusion: Ethanol and water stem extract showed antibacterial activity against MRSA. The independent sample t-test didn't show a difference between ethanol and water stem extract of Andrographis paniculata toward MRSA $(\mathrm{p}>0,05)$.
\end{abstract}

Keywords: Andrographis paniculata's stem extract; ethanol; water; MRSA; in vitro.

*Corresponding author, sinta.devi@student.unud.ac.id 


\section{Introduction}

Methicillin-resistant Staphylococcus aureus (MRSA) is Staphylococcus aureus which is resistant to various classes of antibiotic. ${ }^{1}$ MRSA becomes a major worldwide health problem because it causes nosocomial infection., ${ }^{2,3}$ In Indonesia at three academic hospitals in 2014, there were 366 of 1.502 operating patients have carried S. aureus and 4,3\% carried MRSA. ${ }^{3}$ The MRSA resistance mechanism was first identified in 1981. ${ }^{4}$ MRSA evolved from MSSA through SCCmec acquisition which carried mecA gene. ${ }^{5}$ This gene encoded PBP2a which has a weaker affinity for $\beta$-lactam antibiotic that causes the synthesis of $S$. aureus peptidoglycan was not interrupted when given an antibiotic. ${ }^{6,7}$ MRSA can be classified into HA-MRSA, CA-MRSA and LAMRSA. ${ }^{8}$ Gold standard for infection of MRSA is vancomycin, however, a strain that is less sensitive to vancomycin appears to challenge the role of vancomycin being the first line therapy of MRSA. ${ }^{2}$

Andrographis paniculata is known as sambiloto in Indonesia and it is an annual herbal plant that grows in shady and moist areas with 30$110 \mathrm{~cm}$ in height. ${ }^{9,10}$ Andrographis paniculata has a blood purifying and cold property which consume as herbal tea and jamu in Indonesia., ${ }^{9,11}$ Andrographis paniculata has terpenoid, flavonoid, xanthones, noriridoid and traces element. ${ }^{13}$ Andrographolide is diterpenoid which has antibacterial activity and scattered in each part of Andrographis paniculata with a different concentration. ${ }^{14,15}$ The highest concentration of andrographolide is in the stem. ${ }^{16}$

Andrographolide is an active compound soluble in semi-polar solvent such as ethanol and less soluble in water solvent. ${ }^{17,18,19}$ Andrographis paniculata with ethanol as a solvent has been reported to show antibacterial activity in Doss and Kalaichelvan, 2011, Ganapathy and Karpagam, 2016, Sule, 2011. ${ }^{20,21,22}$ However, andrographolide extraction with alcohol component cause degradation of andrographolide due to esterification. ${ }^{18}$ This study aimed to investigate the antibacterial activity of Andrographis paniculata's ethanol and water stem extract and compare them against MRSA ATCC 3351 in vitro.

\section{Methods}

This study was an experimental study with a post-test only control group design. This study was carried out from February 2019 to October 2019. The extraction process was conducted at Lab. of Pharmacology and Therapy, Faculty of Medicine, Udayana University, while the antibacterial assay was conducted at Lab. of Microbiology, Faculty of Medicine, Udayana University.

Ethical clearance has been received from the Research Ethics Commission Udayana University/Sanglah General Hospital Denpasar with evidence of ethical clearance number: 862/UN14.2.2.VII.14/LP/2019.

\section{Plant collection and sample preparation}

Andrographis paniculata collected from Baturiti village, Kerambitan subdistrict, Tabanan District, Bali Province, Republic of Indonesia. Andrographis paniculata had determined in Plant Conservation Center "Eka Karya" Botanical Garden, Bedugul, Bali Province - Indonesian Institute of Sciences (LIPI). Plants were rinsed off thoroughly and stem part was taken. The stem parts then cut and dried by indirect sunlight through aerated for 7 days. Dried sample than ground into a powder. Extraction was done by the maceration method, $320 \mathrm{~g}$ of powder has solved in 2,8L ethanol $95 \%$ while $240 \mathrm{~g}$ powder has solved in $2,1 \mathrm{~L}$ aquades (1:9 ratio). Maceration products were filtered and were evaporated by evaporator rotary. The extracts were stored in a small container in the refrigerator.

\section{Test Microorganism and Culture}

MRSA ATCC 3351 was acquired from Lab. of Microbiology, Faculty of Medicine, Udayana University, Denpasar, Bali Province, Republic of Indonesia. MRSA was cultured on blood agar with $37^{\circ} \mathrm{C}$ temperature for 24 hours and it was identified with gram staining, catalase test, MSA test, and cefoxitin disc diffusion test. Then, MRSA was subcultured on Mueller Hinton agar (MHA). 


\section{Antibacterial Activity Assay}

MRSA suspension with standard turbidity of $1 \times 10^{8} \mathrm{CFU} / \mathrm{ml}$ smeared on MHA and left at room temperature for 30 minutes. Antibacterial activity observed by the disc diffusion technique in three repetitions. Ethanol $95 \%$ and aquades were used to dissolve the viscous extract. The $100 \%$ concentration consists of viscous extract without solvent. The $50 \%$ concentration consists of $0,25 \mathrm{~g}$ viscous extract with $250 \mu \mathrm{L}$ solvent. The $25 \%$ concentration consists of $0,125 \mathrm{~g}$ viscous extract with $375 \mu \mathrm{L}$ solvent, while the $1 \%$ concentration consists of $0,005 \mathrm{~g}$ viscous extract with $495 \mu \mathrm{L}$ solvent. Blank disc soaked with four extract concentration for 10 minutes. Vancomycin $30 \mu \mathrm{g}$ used as the positive control and blank disc used as the negative control. The disc placed on a petri dish that has been smeared by bacteria. Petri dishes were labeled and incubated at $37^{\circ} \mathrm{C}$ for 24 hours.

\section{Statistical procedures}

Zone of inhibition (ZOI) measured with Vernier caliper and analyze with SPSS 24 version. Data were then analyzed by Shapiro-Wilk test for normality and Levene test for homogeneity. Statistic hypothesis test performed was one-way ANOVA to obtain mean differences between group in each extract. Independent sample t-test performed to compare the inhibitory zone of ethanol and water stem extract at the same concentration.

\section{Result}

Andrographis paniculata's ethanol and water stem extract form inhibition zone against MRSA shown in Figure 1. Shapiro-Wilk test was performed and showed a value above 0,05 that indicated data of this study were normally distributed, while Levene test showed 0,045 value for ethanol extract data and 0,002 for water extract data $(p<0,05)$. It indicated data variances were significance (inhomogeneous). One-way ANOVA showed significance value of $0,0001(\mathrm{p}<0,05)$ for ethanol and water stem extract. It means there are significant differences in ZOI due to the administration of ethanol and water stem extract. The independent sample t-test showed a value above 0,05 when comparing ethanol and water stem extract at the same concentration.
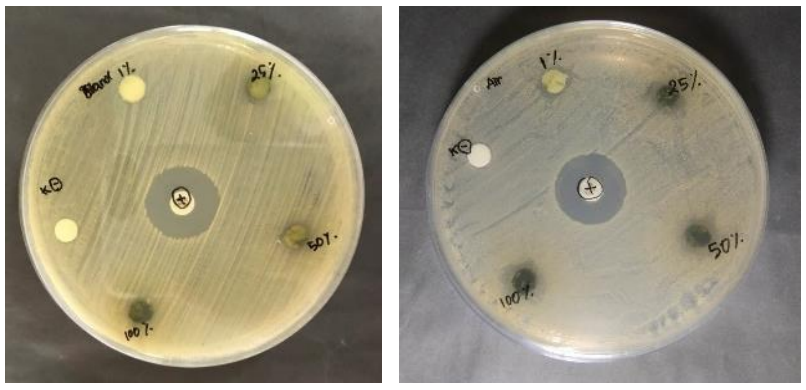

Figure 1. ZOI formed by Andrographis paniculata's ethanol stem extract (left) and water stem extract (right) against MRSA

The mean of the inhibitory zone presented in Table 1 while the result of independent sample ttest presented in Table 2 .

Table 1. Mean inhibitory zone of Andrographis paniculata's ethanol and water stem extract against MRSA

\begin{tabular}{ccc}
\hline \multirow{2}{*}{ Groups } & \multicolumn{2}{c}{$\begin{array}{c}\text { Zone of inhibition } \\
\text { [mean } \pm \text { SD }(\mathbf{m m})]\end{array}$} \\
\cline { 2 - 3 } & $\begin{array}{c}\text { Ethanol } \\
\text { extract }\end{array}$ & $\begin{array}{c}\text { Water } \\
\text { extract }\end{array}$ \\
\hline Blank disc & 0 & 0 \\
Vancomycin 30 $\mu \mathrm{g}$ & $18,77 \pm 0,21$ & $18,80 \pm 0,26$ \\
$1 \%$ concentration & 0 & $4,57 \pm 3,96$ \\
& & \\
$25 \%$ concentration & $5,87 \pm 0,15$ & $7,17 \pm 1,04$ \\
& & \\
$50 \%$ concentration & $6,77 \pm 0,25$ & $8,67 \pm 1,53$ \\
$100 \%$ concentration & $7,87 \pm 0,15$ & $9,67 \pm 1,53$
\end{tabular}

SD: standard deviation

Table 1 showed vancomycin $30 \mu \mathrm{g}$ formed a larger ZOI than Andrographis paniculata's stem extract, while the largest extract concentration formed the largest ZOI than other concentrations. The greater ethanol and water stem extract concentration, the greater the ZOI formed. 
Table 2. Andrographis paniculata's ethanol vs water stem extract

\begin{tabular}{|c|c|c|}
\hline \multicolumn{2}{|c|}{ Concentration of extract } & \multirow{2}{*}{$\begin{array}{l}\text { Sig. (ethanol } \\
\text { vs water) }\end{array}$} \\
\hline Ethanol & Water & \\
\hline $1 \%$ & $1 \%$ & 0,184 \\
\hline $25 \%$ & $25 \%$ & 0,099 \\
\hline $50 \%$ & $50 \%$ & 0,101 \\
\hline $100 \%$ & $100 \%$ & 0,112 \\
\hline
\end{tabular}

Sig.: Significance value from independent sample t-test

Significance value in Table 2 proved that there were no significant differences between Andrographis paniculata's ethanol and water stem extract against MRSA growth.

\section{Discussion}

Ethanol extract of Andrographis paniculata able to inhibit MRSA's growth started from 25\% concentration, while aqueous extract showed the formation of ZOI started from $1 \%$ concentration. That was the lowest concentration that can inhibit the growth of MRSA known as minimum inhibitory concentration (MIC) ${ }^{23}$ According to the formation of ZOI, the inhibitory response of bacterial growth can be divided into four categories. Very strong response if ZOI $\geq 21 \mathrm{~mm}$, strong response if ZOI formed between $11-20 \mathrm{~mm}$, moderate response if $\mathrm{ZOI}$ formed between 6$10 \mathrm{~mm}$, and weak response if $\mathrm{ZOI} \leq 5 \mathrm{~mm} .^{24}$

Based on Table 1, vancomycin $30 \mu \mathrm{g}$ has a strong inhibitory response against MRSA growth. Similar results obtained from Hayati et al., 2012 and Hussain et al., 2019 who reported vancomycin $30 \mu \mathrm{g}$ were having a strong inhibitory response against MRSA..$^{25,26}$ Ethanol extract at $1 \%$ concentration didn't form ZOI and assumed it didn't show antibacterial activity. At the same time, ethanol extract at $25 \%, 50 \%$, and $100 \%$ concentration showed moderate inhibitory response. Similar result obtained from Shalini and Narayanan, 2015 that Andrographis paniculata's ethanol stem extract showed moderate inhibitory response against Staphylococcus $s p .^{27}$ Moderate response also demonstrated by Andrographis paniculata's ethanol stem extract against S. lentus and S. aureus in Xavier and Kumar, 2018. ${ }^{28}$

Different results reported by Ganapathy and Karpagnam, 2016 who obtained ethanol extract of Andrographis paniculata at $100 \%$ concentration showed a very strong inhibitory response against MRSA with $30 \mathrm{~mm}, 28 \mathrm{~mm}$, and $30 \mathrm{~mm}$ of $\mathrm{ZOI}$ in three repetitions. The differences occur because their study uses Andrographis paniculata's whole plant. ${ }^{21}$

Water stem extract at $1 \%$ concentration showed weak inhibitory response, while $25 \%$, $50 \%$, and $100 \%$ concentration showed moderate inhibitory response against MRSA. The similar result of moderate inhibitory response shown by water stem extract of Andrographis paniculata against Staphylococcus sp., Escherichia coli, and Pseudomonas sp. in Shalini and Narayanan, $2015 .^{27}$ Sule et al., 2010 reported the different result of Andrographis paniculata's water extract which shown strong inhibitory response against Staphylococcus epidermis and S. aureus. Their study uses the whole plant of Andrographis paniculata as sample. ${ }^{22}$

The different part of Andrographis paniculata which used as extract affects the antibacterial activity produced. It is because andrographolide concentration which is an active compound with antibacterial activity varies in each part of the plant. ${ }^{29}$ Cheung et al., 2010 stated andrographolide was distributed by $0,61 \%$ in roots, $1 \%$ in leaves, $1,11 \%$ in stems, while $3,545 \%$ in whole part. The origin of sample wasn't mentioned. ${ }^{16}$ Another study reported the biggest concentration of andrographolide was in leaves which were $2,35 \%$, whereas there was only $0,52 \%$ in roots and $0,35 \%$ in stems. Sample collected from the forest in Chhindawara, Balaghat dan Amarkantak, Madhya Pradesh, Dhamtari dan Jagdalpur dan Chhattisgarh. ${ }^{30}$

Different percentage of andrographolide occurs due to diversity of growing location, plant ages, and plant supplementation. Maximum andrographolide percentage obtain from Andrographis paniculata in a location with a moderate temperature $\left(28^{\circ} \mathrm{C}\right)$, while the lowest percentages obtain from Andrographis paniculata which was growing in a plateau with $20-25^{\circ} \mathrm{C}$ of temperature. Other external factors such as sun exposure, growth stages, NPK administration, minerals in the soil and season when Andrographis 
paniculata was growing also influence the quantity of andrographolide. Internal factors such as physiological and biochemical factors and plant morphologies which consist of plant heights, stem diameters, leaf sizes and number of branches also influence andrographolide concentration. ${ }^{31,32}$

Andrographolide acts as an antibacterial agent by impair DNA synthesis of bacteria with the results that disruption of protein and RNA synthesis. This induces the inhibition of downstream pathways on bacterial biosynthesis. Besides, andrographolide plays a role in the inhibition of $S$. aureus's biofilm formation by reducing the formation of polystyrene on bacterial cell surfaces results in the reduction of biofilm thickness gradually as the increase of andrographolide dose. ${ }^{14}$

This study showed the greater Andrographis paniculata's ethanol and water stem extract, the greater the ZOI formed. Whilst, the increase of ZOI wasn't as large as the increase of given concentration. A small increase in ZOI or a decrease in ZOI when increasing extract concentration can occur due to the increase in extract's viscosity. Viscous extract causes an inadequate diffusion of the extract with their bioactive compound to the MHA and on other hands, the active compound doesn't dissolve completely. ${ }^{32}$

Based on independent sample t-test, Andrographis paniculata's ethanol stem extract wasn't significantly different from water stem extract in inhibiting MRSA growth. This result occurs because the extraction of Andrographis paniculata using alcohol compounds causes degradation of andrographolide which is a component of lactone. The opening of the lactone ring was the one of destruction mechanism of andrographolide through trans-esterification. ${ }^{33}$ Furthermore, the extraction of Andrographis paniculata in the alkaline environment causes andrographolide to be degraded to 14-deoxy11,12-didehydroandrographolide and 15-secoandrographolide through dehydration of allyl alcohol and hydrolysis of andrographolide. ${ }^{34}$

\section{Conclusions}

The ethanol and water stem extract of Andrographis paniculata has antibacterial activity against MRSA ATCC 3351 while there is no difference between ethanol and water stem extract which have same concentration against MRSA ATCC 3351. The potential antibacterial activity needs further study. The optimum dose as an antibacterial must be developed. From this study, ethanol and water stem extract of Andrographis paniculata potentially be used as antibacterial in the future. In vivo and clinical evaluation will be conducted.

\section{Acknowledgment}

The author thanks Dr. dr. Agung Wiwiek Indrayani, S.Ked., M.Kes., Dr. dr. Bagus Komang Satriyasa, M.Repro., Prof. Dr. dr. I Made Jawi, M.Kes., and dr. Ni Wayan Sucindra Dewi, M. Biomed. for guidance and advice during this research.

\section{References}

1. Gnanamani, A., Hariharan, P., Satyaseela, M.P. 2017. Staphylococcus aureus: Overview of Bacteriology, Clinical Disease, Epidemiology, Antibiotic Resistance and Therapeutic Approach. In: Enany, S., Alexander, L.E.C. (eds) Frontiers in Microbiology. Croatia: InTech.

2. Rodvold, K.A., McConeghy, K.W. 2014. Methicillin-Resistant Staphylococcus aureus Therapy: Past, Present, and Future. Clinical Infectious Disease. 58 (1):1-27.

3. Santosaningsih, D., Santoso, S., Budayanti, N.S., Kuntaman, K., Lestari, E.S., Farida, H., Hapsari, R., Hadi, P., Winarto, W., Milheirico, C., Maquelin, K., Erix, D.W., Belkum, A.V., Saverin, J.A., Verbrugh, H.A. 2014. Epidemiology of Staphylococcus aureus Harboring the mecA of Panton-Valentine Laukocidin Genes in Hospital in Java and Bali, Indonesia. The American Society of Tropical Medicine and Hygiene. 90(4):728-734.

4. Stryjewski, M.E., Corey, G.R. 2014. Methicillin Resistant Staphylococcus aureus: An Evolving Pathogen. Clinical Infectious Disease. 58(1):10-19. 
5. Sit, P.S., Teh, C.S.J., Idris, N., Sam, I.C., Omar, S.F.S., Sulaiman, H., Thong, K.L., Kamarulzaman, A., Ponnampalavanar, S. 2017. Prevalence of Methicillin-resistant Staphylococcus aureus (MRSA) Infection and The Molecular Characteristics of MRSA Bacteraemia over a Two-year Period in a Tertiary Teaching Hospital in Malaysia. BMC Infectious Disease. 17:274.

6. Jimi, S., Miyazaki, M., Takata, T., Ohjimi, H., Akita, S., Hara, S. 2017. Increasing Drug Resistant of Methicillinresistant Staphylococcus aureus Biofilm Formed on a Mouse Dermal Chip Model. Journal of Medical Microbiology. 66:542550.

7. Deurenberg, R.H., Strobberingh, E.E. 2008. The Evolution of Staphylococcus aureus. Infection, Genetic and Evolution. 8(6):747-763.

8. Grema, H.A., Geidam, Y.A., Gadzama, G.B., Ameh. J.A., Suleiman, A. 2015. Methicillin Resistant Staphylococcus aureus (MRSA): A Review. Advances in Animal and Veterinary Sciences. 3(2):7998.

9. Hossain, M.S., Urbi, Z., Sule, A., Rahman, K.M.H. 2014. Andrographis paniculata (Burm. f.) Wall. ex Nees: A Review of Ethanobotany, Phytochemistry, and Pharmacology. The Science World Journal, 2014: 1-28.

10. Kataky, A., Handique, P.J. 2010. A Brief Overview on Andrographis paniculata (Burm. f) Ness., A High Valued Medicinal Plant: Boon Over Synthetic Drugs. Asian Journal of Science and Thecnology. 6:113-118.

11. Sumiwi, S.A., Halimah, E., Saptarini, N.M., Levita, J., Nawawi, A., Mutalib, A., Ibrahim, S. 2016. Inhibitory Activity of Andrographolide and Andrograpanin on the Rate of $\mathrm{PGH}_{2}$ Formation. Pharmacology and Clinical Pharmacy Research. 1(3):79-83.
12. Elfahmi, Woerdenbag, H.J., Kayser, O. 2014. Jamu: Indonesian Traditional Herbal Medicine Towards Rational Phytopharmacological Use. Journal of Herbal Medicine. 4(2):51-73.

13. Okhurobo, A., Falodun, J.E., Erharuyi, O., Imieje, V., Falodun, A., Langer, P. 2014. Harnessing the Medicinal Properties of Andrographis paniculata for Disease and Beyond: A Review of Its Phytochemistry and Pharmacology. Asian Pasific Journal of Thropical Disease. 4(3):213-222.

14. Banerjee, M., Parai, D., Chattopadyay, S., Mukherjee, S.K. 2017. Andrographolide: Antibacterial Activity Against Common Bacteria of Human Health Concern and Possible Meshanism of Action. Folia Microbiol. 62(3):237-244.

15. Chao, W.W., Lin, B.F. 2010. Isolation and Identification of Bioactive Compounds in Andrographis paniculata (Chuanxinlian). BioMed Central Chinese Medicine. 5(17):1-15.

16. Cheung, H.Y., Cheung C.S., Kong, C.K. 2001. Determination of Bioactive Diterpenoids from Andrographis paniculata by Micellar Electrokinetik Chromatography. Journal of Chromathography. 930(1-2):171-176.

17. Rais, I.R. 2014. Ekstraksi Andrographolide dari Andrographis paniculata (Burm.f.) Ness Menggunakan Eksraksi Soxhlet. Pharmaciana. 4(1):8592.

18. Ratnani, R.D., Hartati, I., Kurniasari, L. 2012. Potensi Produksi Andrographolide dari Sambiloto (Andrographis paniculata Nees) melalui Proses Ekstrakti Hidrotropi. Momentum. 8(1):6-10.

19. Kumoro, A.C., Hasan, M., Siggh, H. 2009. Effect of Solvent Properties on The Soxhlet Extraction of Diterpenoid Lactones from Andrographis paniculata Leaves. ScienceAsia. 35:306-309. 
20. Doss, V., Kalaichelvan, P.T. 2011. In Vitro Antimicrobial and Antioxidant Activity Screening of Andrographis paniculata Leaf Ethanolic Extract in Tamil Nadu. International Journal of Pharmacy and Pharmaceutical Science. 4(1):227-230.

21. Ganapathy, S., Karpagam, S. 2016. In Vitro Evaluation of Antibacterial Potential of Andrographis paniculata Against Resistant Bacteria Pathogens Methicillin Resistant Staphylococcus aureus (MRSA) and Multiple Drug Resistant Escherichia coli (MDR E. coli). International Journal of Bioassays. 5(3):4879-4881.

22. Sule, A., Ahmed, Q.U., Samah, Q.A., Omar, M.N. 2011 Bacteriostatic and Bactericidal Activities of Andrographis paniculata Extracts on Skin Disease Causing Pathogenic Bacteria. Journal of Medicinal Plants Research. 5(1):7-14.

23. Omran, S.M., Armaki, M.T., Zarrinfar, H., Hedayati, M.T., Abastar, M., Moqarabzadeh, V., Ansari, S., Saber, S., Hoseinnejad, A., Miri, A., Verweij, P.E., Seyedmousavi, S. 2018. In-vitro Antifungal Susceptibility Testing of Lanoconazole and Luliconazole Against Aspergillus flavus as an Important Agent of Invassive Aspergillus. Journal of Infection and Chemotherapy. 30:1-4.

24. Yanti, Y.N., Mitika, S. 2017. Uji Efektivitas Antibakteri Ekstrak Etanol Daun Sambiloto (Andrographis paniculata Nees) Terhadap Bacteri Staphylococcus aureus. Jurnal Ilmial Ibnu Sina. 2(1):158168.

25. Hayati, Z., Yulia, W., Karmil, T.F., Azmy, A. 2012. Anti-bacterial Activity of Rosella Flowers Extract (Hibiscus sabdarifa linn) in Inhibiting Bacterial Growth Methicillin-resistant Staphylococcus aureus. The $2^{\text {nd }}$ Annual International Conference Syiah Kuala University. 2(1):416-420.
26. Hussain, M.B., Kamel, Y.M., Ullah, Z., Jiman, A.A.M. 2019. In Vitro Evaluation of Methicillin-resistant Staphylococcus aureua susceptibility to Saudi Honeys. BMC Complementary and Alternative Medicine. 19:185.

27. Shalini, V.B., Narayanan, J.S. 2015. Antibacterial Activity of Andrographis paniculata Nees Against Selective Human Pathogens. African Journal of Microbiology Research. 9(16):1122-1127.

28. Xavier, T.F., Kumar, D.S. 2017. Antibacterial Screening of Andrographis echoides (L.) Nees Against Selected Human Pathogen Bacteria. World Journal of Pharmaceutical Research. 7(1):12121219.

29. Yan, Y., Fang, L.H., Du, G.H. 2018. Andrographolide. In: Du, G.H. (eds.) Natural Small Molecule Drugs from Plants. Singapore: Springer Nature.

30. Pandey, A.K., Mandal, A.K. 2010. Variation in Morphological Characteristics and Andrographolide Content in Andrographis paniculata (Burm.f.) Nees of Central India. Iranica Jornal of Energy \& Environment. 1(2):165-169.

31. Arunkumar, P., Ashok, B., Satyabrata, M. 2013. An Assessment of Andrographolide Production in Andrographis paniculata Grown in Different Agroclimate Locations. African Journal of Agricultural Research. 8(48):6101-6109.

32. Nomer, N.M.G.R., Duniaji, A.S., Nocianitri, K.A. 2019. Kandungan Senyawa Flavonoid dan Antosianin Ekstrak Kayu Secang (Caesalpinia sappan L.) serta Aktivitas Antibakteri Terhadap Vibrio cholerae. Jurnal Ilmu dan Teknologi Pangan. 8(2):216-226. 
33. Wongkittipong, R., Prat, L., Damronglerd, S., Gourdon, C. 2004. Solid-liquid Extraction of Andrographolide from Plants-Experimental Study, Kinetic Reaction and Model. Separation and Purification Technology. 40 (2004):147154.
34. Phattanawasin, P., Sotanaphun, U., Burana-osot, J., Piyapolrungroj, N. 2018. Isolation and Characterization of The Acid and Base Degradation Products of Andrographolide. Pharmazie. 73:559-562. 